\title{
Influence of Enviromental Factors on Financing of Public Irrigation Projects in Kenya
}

\author{
Quinter Omware Owawa ${ }^{1}$, Alice Emily Osoro ${ }^{2}$ \\ ${ }^{1}$ Department of Education and External studies, University of Nairobi, Nairobi, Kenya \\ ${ }^{2}$ College of Human Resource Development, Jomo Kenyatta University of Agriculture and Technology, Juja, Kenya
}

Email address:

qokeyo@gmail.com (Q. O. Owawa), alice.osoro@gmail.com (A. E. Osoro)

\section{To cite this article:}

Quinter Omware Owawa, Alice Emily Osoro. Influence of Enviromental Factors on Financing of Public Irrigation Projects in Kenya. International Journal of Economics, Finance and Management Sciences. Vol. 3, No. 3, 2015, pp. 260-269. doi: 10.11648/j.ijefm.20150303.22

\begin{abstract}
Project finance (PF) is a relatively new concept in developing countries as opposed to developed countries. PF has been used in development of Infrastructure in Energy sector (oil and gas, mining, electricity generation), water sector, telecommunication, roads and highway, railway, Irrigation and public services. Different scholars and experts have worked on development on infrastructure projects in different sectors using PF concept, even though the PF concept has been used few studies have been done on Irrigation sector. The purpose of this paper is to analyze Influence of environmental factors on financing of irrigation projects; by critically looking at its use in other sectors in comparison to irrigation sector. In examining these aspects, an attempt is made to achieve four main objectives: to determine Key Commercial Risks involved, analyze Main contractual forms of PPPs in Irrigation, to determine Key Legal issues involved and to generate proposition for future empirical studies.
\end{abstract}

Keywords: Environmental Factors, Financing, Public Irrigation Projects

\section{Introduction}

\subsection{Background of the Study}

The concept of infrastructure project finance has been used since beginning of 13th century and has attracted a number of studies from scholars over the world. So far, there is no generally accepted definition in the literature available on the subject of PF. There is a general agreement that the concept of project finance focuses on three fundamental aspects (Benjamin and Aldo, 2007). Firstly, the investment should be capital-intensive in nature with the capability to derive long-term surplus. Secondly, the definition also highlights the organizational aspects of project finance through the creation of a legally-independent entity that owns the project assets. This legally-independent entity is the 'Special Purpose Vehicle' (SPV) or a 'project company', to which government, municipality or other public bodies award a 'concession' or a 'license', based on which it has exclusive rights to use/operate an asset for a fixed number of years. At the end of the concession the asset is handed back to the public sector in a pre-specified condition. Standard \& Poor's Corporation (2003, p. 23) defines a project company as “.... group of agreements and contracts between lenders, project sponsors and other interested parties that create a form of business organization that will issue a finite amount of debt on inception; will operate in a focused line of business; and will ask that lenders look only to a specific asset, to generate cash flow, as the sole source of principal and interest payments and collateral" (Rigby and Penrose, 2003).

Project finance has proven to be a useful financing technique throughout the world and across many industry sectors (Buljevich \& Park, 1999; Esty, 2004b; Fabozzi \& Nevitt, 2000; Gulati, 2013). Project finance has long been used to fund large-scale energy projects(such as power generation facilities, oil and natural gas pipelines, electric utilities, chemical plants, water and waste water treatment facilities, renewable energy and green technologies, etc.) both in the developed world as well as developing countries. The percentage of capital investment worldwide that is financed on a project basis is likely to increase in the future.

According to Rajan \& Zingales (2003) there should be a clear distinction between project finance and conventional direct finance. They argue that in direct finance model, lenders look to the firm's entire asset portfolio to generate the cash 
flow to service their loans, while in the project finance model, lenders look to the single project as a distinct legal entity. Therefore, main difference between corporate finance and project finance is that the assets are financed as stand-alone entities rather than as part of a corporate balance sheet. This agrees with earlier argument by Drew (1995) that the project must be able to generate sufficient funds to cover all operating costs and debt service while still providing an acceptable return on the equity invested in the project. Hence, project finance depends on a detailed evaluation of a project's construction, operation, revenue risks, and their allocation between investors, lenders, and other parties through contractual and other arrangements.

This paper examines Influence of environmental factors on financing of irrigation projects. The article will be limited to a discussion of three aspects of PF these are: Extent to which key commercial risks influence financing of irrigation projects, Analyze the key legal issues in financing of irrigation projects and Impact of contractual forms of PPP

\subsection{Statement of the Problem}

According to Vaidya, Sajeev and Callender (2006), while public procurement is one of the core functions of the government, it had been and continues to be neglected by academicians and researchers. This had created a knowledge gap making it a challenge for governmental entities, policy-makers, and public procurement professionals to make decisions relating to adoption of new technologies and emerging procurement trends. E-Procurement is one of the reforms that have been adopted by the government of Kenya to enhance public procurement operations. In ideal conditions, adoption of e-procurement is expected to bring sanity in the procurement operations, reduce costs and enhance efficiency. For many organizations, including public organizations, the objectives of adoption of e-procurement include: enhance efficiency, improved accountability and transparency and reduced costs. However, many organizations adopt e-procurement strategies without clear understanding on what to expect. To understand the concept of e-procurement and the associated benefits, a number of studies had been done. For instance, studies have been done on implementation of e-procurement, challenges of implementation of e-procurement and benefits of e procurement. Studies had also related e procurement with other variables like operational and overall organizational performance. A few studies had related e-procurement with procurement performance while none had studied such relationship in the county governments. Since the adoption of devolved system of government in Kenya in 2013, Kenyan public procurement has been devolved. Just like the national government, the county governments are implementing e-procurement. Since no study had been done to relate e-procurement and procurement performance of county governments, there existed a knowledge gap as to the relationship between e-procurement and procurement performance among county governments. Such gaps needed to be filled through research. This study intended to bridge this gap by investigating the effect of e procurement on procurement performance of county governments.

\section{Literature Review}

\subsection{Theoretical Framework}

Moris, Kuratko \& Schindehutte, (2001) describes theoretical framework as explanations about the phenomena which provide the researcher with a lens to view the world clearly. The conceptual understanding of Application of Project Finance in Development of Irrigation Infrastructure is based on, Capital Asset Pricing Model (CAPM) and Prospect theory.

\subsubsection{Capital Asset Pricing Model (CAPM)}

The capital asset pricing model was the work of financial economist (and, later, Nobel laureate in economics) William Sharpe, set out in his 1970 book "Portfolio Theory and Capital Markets."Capital asset pricing model describes the relationship between risk and expected return and that is used in the pricing of risky securities. The rational for choosing CAPM, is to assist investors interested in development of Irrigation infrastructure to choose on only non-diversifiable risks which are rewarding within the scope of this model.

CAPM helps to determine what return are deserved for putting money at risk. It describes how investors can choose the right alternatives involving risks and opt for right financial decisions. I $t$ also describes how investors evaluate potential gains and losses. His model starts with the idea that individual investment contains two types of risk: Systematic Risks also known as Un-diversifiable risk - These are market risks that cannot be diversified away.

Systematic risk refers to the risk common to all securities (market risk) i.e. Interest rates, recessions and wars are examples of systematic risks. CAPM thus holds that all investors who take systematic risks are compensated by the market place. Specific Risk, also known as Unsystematic Risk or diversifiable risk, this risk is specific to individual stocks or individual assets and can be diversified away as. It represents the component of a stock's return that is not correlated with general market moves. Market place never compensates investors who are taking specific risks since specific risks are compensated through certain processes. The risk of a portfolio comprises systematic risk and specific or unsystematic risk which is also known as idiosyncratic risk or diversifiable risk. Unsystematic risk is the risk associated with individual assets. Unsystematic risk can be diversified away to smaller levels by including a greater number of assets in the portfolio (specific risks "average out"). The investor increases the number of stocks in his or her portfolio.

The same is not possible for systematic risk within one market. Depending on the market, a portfolio of approximately $30-40$ securities in developed markets such as the UK or US will render the portfolio sufficiently diversified such that risk exposure is limited to systematic risk only. In developing markets a larger number is required, due to the 
higher asset volatilities.

\subsubsection{Prospect Theory}

The theory was developed by Daniel Kahneman and Amos Tversky in 1979 as a psychology It is a behavioral economic theory that describes the way people choose between probabilistic alternatives that involve risk, where the probabilities of outcomes are known. The theory states that people make decisions based on the potential value of losses and gains rather than the final outcome, and that people evaluate these losses and gains using certain heuristics, more accurate description of decision making, comparing to the expected utility theory. The rational for choosing Prospect Theory, is to assist Specially Purpose Vehicle (SPV) allocated the right risks to partners who are best suited to tackle them.

\subsection{Financing of Irrigation Projects}

Irrigated agriculture has made a major contribution to food production and food security throughout the world: without irrigation much of the impressive growth in agricultural productivity over the last 50 years could not have been achieved. Nevertheless it is widely accepted that the overall performance of 'irrigation and drainage' (also implying reclamation and water control) investments has too often fallen short of the expectations of planners, governments and financing institutions alike (Ref: Report No. 13676,A Review of World Bank Experience in Irrigation, Operations Evaluation Department, World Bank, Washington DC, 1994). Examples of successful irrigation projects which have been executed are; Brazil-Pontal Public-Private in Irrigation and Egypt west delta. In Kenya, Multi-Billion Dollar Galana/kulalu Irrigation project is in its initial stages of execution.

The term "infrastructure" could be defined in various aspects but in relation to this article. We will define it as the provision of essential services and amenities to the industry and households in the society (Martini and Lee 1996). Hence, investment in infrastructure development projects is a key input in the development of the economy and a panacea to economic activity and growth. However, what is regarded as "essential", "key" and "panacea" changes from one country to another and from one period of time to another. For instance, the massive production of steel, coal and iron ore was once regarded as indispensable infrastructure. Recently, some activities that are considered as infrastructure investment and finance includes: Telecommunications (WiFi, WiMax, Broadband, GSM and CDMA etc); Social infrastructure (hospitals, modern prisons, courts, museums, schools and Council and Government housing); Energy (Renewable energy i.e. solar and wind, power generation, distribution, transmission and supply); Transportation (light rail systems, bridges, tunnels and under-ground/over-ground high speed trains, toll roads ); Water (Water supply, dams for irrigation, water, liquid and solid treatment plants, sewerage ).These share with other types of fixed investment (for instance in the property development, office block construction (Lewis,
1994). According to Dixit and Pindyck (1994); Adam (1996) both argued that some of the common characteristics seen in fixed investment are as follows:

Valuation (the projects are difficult to value because of taxation, fixed choices and pricing rules and regulation) Duration (infrastructure is long-lived, and has a long maturation period); Illiquid (the lumpiness and indivisibility of infrastructure projects makes for a limited secondary market); Capital intensive (projects are large in nature and also highly geared);

The result is that evaluation of the projects is a complicated and dedicated activity. The basic indicator used to be that infrastructure had to be provided by government-owned establishments which was previously the main approach in Europe or by privately owned services, subject to rate of return regulation which is the approach of most states in the United States. This belief resulting from a number of intrinsic characteristics, such as the existence of: Externalities: This is the situation whereby costs and benefits are bestow upon those that are not a party to the transaction (e.g. spillovers); Natural monopolies: This is the situation whereby economics of scale make it efficient and adequate to have only one provider (for instance, Water Corporation, an electricity grid, and in some extent power generation, transmission and distribution. Public goods: This is the situation from which it is complicated (and perhaps not desirable) to exclude non-payers (the non-excludability principle); Network services: Here, it involves providing integrative activities which connect economic activity together. Consequently, the drift away from public to private sector provision of infrastructure development has been underpinned by a distinct change in philosophy and practice on this subject matter. There has been the view and analysis, for example, that a shift from 'taxpayer pays' to 'user pays' (i.e. from ability-to-pay to the benefit principle) in the provision of critical infrastructure development projects such as (water, power, sanitation and roads high-way construction) is probable to be associated with an improved profitable use of the services. However, numerous previous industries considered to be inherent monopolies, e.g. electricity network, generation, transmission and telecommunications, have been broken up into different geographical regional firms or, with deregulation, divided into competitive (or potentially competitive firms) sectors vis-à-vis those sectors that remain inherent monopolies (the distinction between power supply and high-voltage transmission, and between railway operation and rail track services).In those other activities which have inherent monopoly features, replacement of price-cap regulation for rate-of-return regulation (i.e. fixing of maximum process rather than the mark up over costs) has produced strong motivation to reduce costs, while third party access to certain facilities that are not economic to duplicate has expanded successful competition in the upstream and downstream trades served by the facilities. All of this has laid the foundation for PPP financial arrangement (Grimsey and Lewis 2002).

Most of the infrastructure projects are large in size and 
require a lot capital outlay which cannot be executed by an individual, public sector or private sector alone, hence calls for the formation of Public Private Partnership (PPP). Many scholars have been challenged; confronted by attempting to improve the operation of PPP projects by categorizing major aspects of these projects (Erridge and Greer, 2002; Grimsey and Lewis, 2002; Li et al., 2005b; Tang, L et al. 2009). The use of PPPs to substitute and harmonize the Public Sector Provision (PSP) of infrastructure has become common in recent years. In the modern era of infrastructure development, projects that require complex, innovative, and large upfront investments, such as the financing and construction of bridges, seaports, airports terminals, sewage and renewal energy facilities, light and speed rails, highways, schools and hospitals are now frequently provided through the means of PPPs. There exist three extensive options of organizational forms in the provision of infrastructure development: such as PSP, PPPs and privatization, perhaps under a regulated monopoly. Each of these forms includes a number of contractual arrangements, for instance, According to Guasch (2004) there are as many as 12 measures, structured with the intention of increasing private participation. They are as follows public supply operation, outsourcing, corporatization and performance agreement, management contracts, leasing (also known as affermage), franchise, concession, build-operate-transfer (BOT), build-own-operate, divestiture by license, (also known as sale, and private supply and operation. Our definition of PPPs includes the four cases grouped by Guasch as concessions, namely leasing, franchise, concession, and BOT. In this article we use the terms PPPs, Private Finance Initiative (PFIs) and concession interchangeably.

According to Yescombe (2007), the growth and spread of PPPs around the world is very much connected to the development of project finance, a financial method based on lending against the cash stream of a project that is legally and economically self-contained. As shown in Figure 2, this is guarantee by forming a Unit/Company called Special Purpose Vehicle (SPV), which does not undertake any business other than building and operating the project (Yescombe 2002, p. 318). The sponsor of the construction or infrastructure development projects set up a Unit/Company called Special Purpose Vehicle (SPV) before going to take part in the bidding process. The sponsor is also the main equity investor who is responsible for bidding, developing and managing the project. They are the residual plaintiffs and are indispensable to the success and completion of the project. This means that lenders (banks, lending organizations) will vigilantly examine the features, attributes and qualities of the sponsor before committing capital and funds. Sponsors can be operational and play double roles, in the sense that they belong to the industry, and will get business for themselves as subcontractors; or financial sponsors, who are involved in the financial arrangements for the project. Levy (1996) point out that the Queen Elizabeth II Bridge over the Darford River in the UK is an example of the first type of sponsor: the construction division of Trafalgar House Plc organized local landowners plus an investment bank and presented an initial proposal to the government. The Department of Transport approved the proposal and, after looking at other bids, awarded the project to Trafalgar House. Another example in which the main sponsor was a family- owned Investment Company is the Dulles Greenway project in Virginia, which started operating in 1995, with the sponsor 57.04 percent of property (Toll roads investors Partnership II). (See levy 1996).

\subsection{Key Commercial Risks}

Extent to which Key Commercial Risk Influence Financing of Irrigation Project

Knowing the specific risk factors of the projects is a prerequisite to manage its structure, by including further guarantors or creating a risk structure that is acceptable for all parties concerned. The risks of financing an infrastructure project refers to all the "possibilities" of delays or differences in returns to that which investors would receive if everything went according to plan. The distinctive nature of large infrastructure projects implies that investors face risks that differ from those of typical productive investment (Griffith-Jones, 1998): - a combination of high capital costs and low operating costs implies that financing costs are a very large proportion of the total; - long construction periods are most often combined with slow buildup of revenue - the project's cash flow is the crucial element in the return to equity investors and in the security of the lenders (in the absence of public guarantees) Most of the risks related to an infrastructure project can be found in any country. However, the financial risk of exchange rate fluctuations, as well as regulatory risks with the host government is particularly large in developing countries. Those two risks were identified in our research as of most concern. Currency devaluation still leads as the main obstacle to attract long term investment, although recently local currency bonds and liquidity facilities offer some relief. In an infrastructure project there are two main categories of risk: commercial and political risk.

Commercial risks are risks that may affect the commercial operation of the project, including construction delays and cost overruns, increases in operating and maintenance expenses, changes in prices of inputs and outputs, availability and quality of supplies, and contractor insolvency. Additionally, commercial risks are all risks relating to: construction of the facility, markets, operating phase and finance. The commercial risks are generally within control or management of the project sponsors. This is in contrast to the political risks, mostly under the control or influence of the Government. Political risk arises from the fact that some unforeseen event may change the project's prospects for profitability. Political risks might be caused by actions (such as changes of laws that adversely affect project economics) or inaction (i.e. not approve an expected tariff increase or approval delays) by the government. Each phase has a different risk profile and financing requirements. Because of the varying characteristics of these phases both equity investors and lenders can be expected to seek different 
rewards and require different guarantees, depending upon which of these different phases they are required to participate in (Griffith-Jones, 1993:16). 5 Projects, which have cash flows generated in foreign currency, such as oil, gas and power utilities9, are less troublesome since currency risks of the foreign investors are partially mitigated 10 . Most large project finance transactions are restricted to schemes that can generate revenues in hard currency or are linked to hard currency.

According to (Tirole, 2006; Yescombe, 2007; Engel et al; 2010), banks carry out a supervising role that is well coordinated to moderate moral hazard by implementing firm control over wanton changes to the project's contract, the character and actions of the SPV and her contractors. In order to control their character and actions adequately, banks gradually distribute finances only when each project stages are completed accordingly. Further, after completion and ramp-up of the project, suddenly the risk falls and is limited to events that may influence cash streams. This is the appropriate period for bond finance since bond shareholders' are more concerned about proceedings that drastically affect the security of the cash streams, but are not directly involved in management, or in control of the PPP infrastructure development project. Indeed, this is suitable for organizational and other non-active investors who by statutes can invest only limited amounts of their resources in the preliminary stages of a PPP infrastructure project due to high risk. According to Engel et al, 1997b, Engel et al., 2001 and Engel et al., 2010 the amount of incomes and proceeds accruing to SPV depend on the availability of the project, the level of end user fees and charges, the real demand volume and the contractual term agreement. The importance of each factor differ from one project stage to another, but incomes can be classified along two elements, such as The source of payments, The extent to which the SPV is made to bear demand risk.

Unlike other sectors, irrigation projects are self-contained investments which are linked solely to the local off-take, i.e. the viability of the agricultural activities using the water. Infrastructure providers are thus exposed to market and commodity risks. Commitments, through management or finance, will only be forthcoming if private-sector partners can have a degree of certainty that they will be able to recover their investments. Since water is one input into the production process, in addition to management, credit, fertilizer and access to market, the ability and willingness to pay (WTP) for water services must be considered in the context of overall farmer capacities. The less certain private partners are that they will recover their time and financial commitments, the lower their appetite for participation and the greater the need for concessional or public-sector resources. Farmer capacity and agricultural productivity are themselves only one determinant of the private-sector's ability to enforce financial obligations of project participants. This means mechanisms for payments between smallholders, farm managers and irrigation providers; overall incentives for farmers to meet obligations under the scheme; and the design of land arrangements such as the terms of access to consolidated land, selection of farmers for high potential allocations, and procedures to incentivize farmers who do not pull their weight. The institutional organization of farmers with typical Relationships Between Private Operator and Farmers in PPPs.(Ref: Report No. 13676, A Review of World Bank Experience in Irrigation, Operations Evaluation Department, World Bank, Washington DC, 1994).

The following are the main types institutional arrangement that are typically used in Irrigation PPPs: Commercial farmer as a private irrigation operator: Smallholder farmers in the command area would be given the option of becoming out growers to the large commercial farmer. Engaging farmers as out growers involves: Providing them with seeds and other inputs required to grow a certain crop, Training them in growing the crop, Specifying quality standards the harvested crops must meet and purchasing the harvested crops from them at an agreed-upon price. Farmers responsible for maintaining the tertiary network: The private operator will be responsible for all aspects of operating the irrigation system up to the farm level, and of maintaining the system up to the tertiary canals. Farmers, through their water user associations (WUAs), are responsible for maintaining the tertiary network The private operator is responsible for operating and maintaining the entire system, and farmers pay a tariff that covers operating and maintenance costs. Farmers are not responsible for operating or maintaining the irrigation system. Determine these features, for example through cooperatives, trusts and water user associations. Drawing on the above rationale, it is proposed that:

Proposition 1: Irrigated agriculture projects, especially those involving smallholder farmers, are difficult to fund on a commercial basis from day one because they cannot deliver short-term predictable financial returns.

\subsection{Main Contractual Forms of PPPs in Irrigation}

Contractual Forms of PPP and how they Influence Development of Irrigation Infrastructure

The most commonly used contractual forms of PPP in the irrigation sector:

OMM contract: The private-sector is engaged to undertake operation, management and maintenance (OMM) of infrastructure services for defined recipients. The private-sector provides a service for which it receives a fee (either from the government or from users). Where rehabilitation or construction works are required, they can also be part of the contract. Assets are publicly financed, and this is an appropriate form of contract where there is limited scope to raise private capital.

Infrastructure concession: The private-sector is engaged to raise commercial finance for infrastructure development and then construct, operate, manage and maintain the infrastructure. Investment and financing costs must be recovered through fees (either from the government or from users). End user risk is significant in irrigation projects where often the users are not fully defined at the beginning of the project (it depends on how many farmers take up the water 
from the system). It might be possible to share end user risk between the public and private parties, for instance with a guarantee on minimum revenue. The investment may be undertaken in whole or in part by the private sector where for instance there is grant funding available to bear some of the investment cost.

Farm service agreement: The private-sector can also partner with smallholder farmers and communities for the provision of farm-level services. Services might be on-farm, such as planting, harvesting and water application; or off-farm, such as storing, processing and marketing (e.g. out grower services). Such farm services, by improving the agricultural performance of water users, are likely to improve the viability of irrigation infrastructure. The level of investment private finance required depends on the services provided. Farm services can be integral or separate from infrastructure OMM.

Hub farm agreement: The private-sector can be engaged to undertake commercial agricultural production through a land concession or lease. This might be on unoccupied land owned by the government or third-parties, or community land held under collective title (or especially consolidated) and leased in return for a fee of share in commercial operations. The hub farm has purely commercial aims, and will require a certain scale in order to offer commercial opportunities (especially for food crops). Private capital is required for on-farm investments, while irrigation fees can reflect any or all infrastructure related costs (e.g. OMM, investment and finance). Adapted from (Ref: Report No. 13676, A Review of World Bank Experience in Irrigation, Operations Evaluation Department, World Bank, Washington DC, 1994)

Drawing on the above rationale, it is proposed that:

Proposition 2: Key characteristics of a project that determine the PPP model include the extent of investment needed for new assets, the experience of smallholder farmers, and the (social, technical and commercial) feasibility of hub-farm investments.

\subsection{Key Legal Issues that Arise in Irrigation PPPs}

\subsubsection{Impact of Key Legal Issues in Development of Irrigation Infrastructure}

There are a number of legal and commercial issues that will affect how these projects move forward and are structured. While some of the legal issues are not confined to irrigation PPPs they can take on a new dimension and complexity when applied to irrigation:

Land ownership: all irrigation projects are dependent on land ownership - both in relation to the land that is needed for the project, and also in relation to the customers for the project, the farmers, and their legal interest in the land. Some countries limit land ownership to locals or may prohibit ownership in private hands. For instance, in Ethiopia, rural land is owned by the government and only individuals who were willing to farm personally are entitled to possess land.

There may also be difficulties with establishing land title, particularly in countries where there are significant customary land rights - such as Ghana and many other sub-Saharan African countries. There may also be restrictions on land use, irrigation or types of irrigation may be restricted - and the rules may vary within a country from state to state or county to county.

Water extraction: there may be limitations on levels of water extraction, both at national and international level. If extraction from a river or other water source is subject to international waterways, then there may be restrictions on the amount of water that can be extracted. For instance, countries in the Nile Basin are limited by treaty under the Nile Basin Initiative to the amount that may be extracted and for what purpose. In federal countries, water rights may be licensed and, for instance in the case of the USA, traded between states.

It may also be difficult to determine who has the power to grant permits to extract the water. This may involve the ministry of water or the ministry of the environment, or sometimes both. Water user associations may also play a role. In cases of scarcity or where there are systematic droughts, there may be a priority imposed by law or regulation on which users get water in times of shortage. This may be particularly relevant where there are competing users - for instance hydroelectric power projects or downstream users.

The regimes for charges for water extraction may be complex and/ or vague. It may be difficult to determine if and how they are these set, who sets them and whether there are different rules for charging for raw water and for irrigation. These will be key issues in a PPP as the private provider will want to ensure a steady revenue stream and so will want to be sure of the price that it is buying raw water, the price that it can on sell irrigation water and the quantities that it can extract and sell.

Public Sector Counterpart: in irrigation PPPs it can be difficult to ascertain which public institution will be responsible for developing the project and the signatory to the project agreement - in most emerging markets where PPPs have been used for developing irrigation systems, the national entity in charge of irrigation services would be the counterparty to the PPP contract. In Egypt for example, the Ministry of Water Resources was the relevant counterpart for the proposed West Delta irrigation project. However, as noted above, where there are competing claims from the authority responsible for water resources or the ministry of environment, this can be confusing. It may also be a more local rather than a national entity that is responsible for the project. Another key issue in this regard is whether the relevant entity has the power to enter into PPP arrangements. In the case of a sub-national authority or a parastatal, it may need express power to do so.

There are also the usual legal considerations that need to be checked when developing PPPs in any sector, such as legal restrictions on the type of PPP arrangement that can be entered into, relevant procurement rules for entering into PPPs, existence of restrictions on foreign investment, taxation and potential for tax holidays and the ability to assign rights such as security and step in rights to lenders, 
adapted from (Ref: Report No. 13676, A Review of World Bank Experience in Irrigation, Operations Evaluation Department, World Bank, Washington DC, 1994). Drawing on the above rationale, it is proposed that:

Proposition 3: There are many legal issues involved in infrastructure development but the Key legal issues confined to Irrigation PPP Involves land ownership, water extraction and public sector counter parts.

\subsubsection{Examples of PPP and Sample Agreements}

Brazil - Pontal Public-Private Partnership in Irrigation (English); this project established a public-private partnership (PPP) for common use irrigation infrastructure in an area of 7,717 hectares for commercial agriculture in the Pontal region of Brazil, State of Pernanbuco. The government would cede the land and the existing infrastructure, already covering a significant part of the target area. The private partner would operate and manage and further develop the infrastructure to ensure (1) the area is fully irrigated within six (6) years of the date of signature of the contract; and (2) that at least $25 \%$ of the irrigated land is available for small farmers, who should be integrated into the production chain of the commercial producers that would occupy the remainder of the land. The private partner will be remunerated for the sale of water (through user tariffs) and a capacity payment by the government. Pontal Public-Private Partnership in Irrigation Concession Agreement (English), Invitation to Bid PPP In Irrigation, Edital de Licitação com anexos Invitation to Bid (Portuguese), Contrato de Concessão Patrocinada (Portuguese).

Egypt-West Delta, West Delta - The public-private partnership for the West Delta Project is designed as a hybrid scheme based largely on the design-build-operate (DBO) model. The transaction essentially involves contracting a private operator to take over a concession area consisting of about 79,800 hectares in the southern part of the West Delta, to design and construct the system, and to assume full operational responsibility for 30 years, including the associated demand and commercial risks. The public sector will assume ownership of the assets and take on most of the financing-related responsibilities and risks. These include the currency risk associated with a potential devaluation of the Egyptian pound. The decision process from design to execution is innovative in that it involves users from the conception, incorporates a water user council, and adopted a two-part tariff: farmers would pay both an annual fixed fee based on the land area connected and a volumetric fee based on the amount of water use.

Peru - Olmos Irrigation Project (English). The Olmos Irrigation Project concession involves the irrigation of 38,000 hectares of New Land owned by the Lambayeque Regional Government (GRL, Spanish acronym) and 5,500 hectares of lands in the Valle Viejo and 'Santo Domingo de Olmos' Rural Community by means of the development of hydraulic infrastructure. The concession is a Build-Own-Operate-Transfer where the Government of Peru auctions the land to be irrigated, the proceeds of such sale finance the construction of the irrigation infrastructure, and the private partner develops the necessary works to operate adequate irrigation services. The Private partner then manages and charges for irrigation services. The term of the concession is 25 years. Olmos (Peru) PPP Contract for Irrigation in Spanish (Contrato de Concession para PPP enIrrigaci ón Olmos).

Kenya- Galana/ Kulalu Food Security Project - Model Farm Construction

Galana Ranch situated in Tana and Kilifi Counties was bought by ADC from Galana Game and Ranching Company Ltd in 1989. The Ranch measures approximately 1.5 million acres. The Ranch is currently under leasehold for a term of 45 years with effect from November, 2011. Kulalu Ranch is located in Kilifi County and measures 239,487 acres and was leased to ADC by the Government for a term of 45 years with effect from August 1983. Currently, Galana ranch has a total of 4,870 beef herd, 1,400 goats and 800 dorper sheep.

Officially Galana ranch is leased to several companies and investors who have put up temporary tented camps adjacent to the Galana River for eco-tourism purposes in both Galana and Kulalu. Currently the following has been done; development of 10,000 acres model farm (Bush clearing), Rehabilitation of and expansion of 19 No water pans ,design of new 14 water pans, rehabilitation of roads, Bush clearing $202 \mathrm{~km} \quad$ (200), Murraming 87.6km,Grading $190 \mathrm{~km}$ (150), Rehabilitate 2No. Airstrips, detailed study on soils and design of the project is on progress

This project has been designed to attract Private Partners in funding of its implementation. Leases will be done also to private individuals to carry out development in Irrigated agriculture, livestock, and pasture and eco-tourism.

\subsection{Guarantees}

Guarantees are very suitable instruments for long term infrastructure projects. As regards to hedging and derivatives as alternative ways to mitigate currency risk, there are several constraints: Derivatives markets do not exist for many currencies, Long-dated forward exchange rates exists only for a few non-OECD countries that have investment ratings, It is therefore unlikely in most cases that forward foreign exchange transactions could be arranged at an affordable cost with sufficient tenor to serve as basis for financing infrastructure projects. The instruments to mitigate economic risks are numerous.

\subsubsection{Available Loan Guarantee Mechanisms}

The ones that involve loan guarantee mechanisms and are relevant to this study include: Mix local currency and foreign currency loans, Cover as much of the project as possible with local currency finance, to avoid excessive reliance on foreign funds. This reduces currency risks, since both assets and liabilities will be in local currency. Index output prices to exchange rate. Swap currency, If possible local currency should be readily swapped with a major foreign currency to remove project's currency risks. This is applicable especially during the initial phase of mobilizing funds for the project. 
Contingency sponsor support - Foreign sponsors can pledge contingency foreign currency support in various ways. Escrow account - When a project earns convertible hard currency, its foreign earnings can be deposited in a special escrow account.

The financial market has developed sophisticated structures to mitigate risks of long-term investment such as infrastructure projects in developing countries. Nonetheless, there is an eminent need for effective loan guarantee mechanisms to deal with currency and regulatory risks. Although government in developing countries offer guarantees and protection to foreign investors, their financial capacity to deliver on such commitments is in doubt. Project finance plays a crucial role in infrastructure financing. To the greatest extent possible, project sponsors absorb commercial risks. Some financial risks can be shared with creditors under project financing. But creditors usually devise security packages to protect themselves. Only when such packages fail to yield sufficient value does the risk of an actual loss materialize for a creditor (Mistry, 2003:29).

\subsubsection{Multilateral Development Banks}

Multilateral Development Banks have a special role in assisting private enterprises undertake financially viable projects with significant economic and social merit, and therefore achieve positive development impact. Multilaterals are in a unique position to assist in mobilizing international private capital. The direct participation of multilaterals in private sector activities provides an additional attraction to long-term investors, by providing comfort to them. Innovative financial solutions involving a mixture of private and official funding sources may be needed for commercial lenders and equity investors to manage the risks associated with investing in developing countries.

\subsubsection{Export Credit Agencies}

Export Credit Agencies (ECAs) are supported or owned by a government, and exist to support and encourage the sale of capital goods. ECAs and investment insurance agencies often work in partnership with multilateral development banks (MDBs) to finance capital and infrastructure projects in developing countries. ECAs employ many of the same risk reducing instruments that the World Bank Group relies on, such as investment insurance and, political and commercial risk guarantees. While multilateral banks accounted for roughly 17 percent of developing country debt during the 1990s, ECAs accounted for 31 percent (Esty, 2003). From 1994 to 1999, ECAs provided some form of support for just under half of all financing for energy intensive projects. ECA financing is most heavily concentrated in oil and gas development and fossil-fuelled power generation. The overwhelming share of ECA financing was provided by the world's seven leading industrialized economies (World Resources Institute, 2002). ECA guarantees are especially important for BOT projects, since those were meant to relieve the government of the burden of carrying in its budget capital intensive projects that can be done by private investors. These projects generate employment and increase domestic demand on account of their linkages to other industries.

\subsubsection{Guarantee for Local Currency Bonds}

The objective of this instrument is to create and direct credit enhancement of domestic long-term debt issues for infrastructure projects to foreign investors. The guarantees for local currency bonds should be a blend of the guarantees available for domestic investors plus a focus on avoiding currency shocks. As previously said, the lack of available coverage for currency volatility represents an important market failure to be addressed. The development of more efficient local markets avoids currency mismatch.

\subsubsection{Alternative Guarantee Mechanism to Overcome the Currency and Regulatory Risks}

Liquidity Facilities: The conceptual operationalization of foreign exchange liquidity facility (FELF) is relatively simple. It aims to separate currency from operational risk. The parties involved firstly should agree upon a "floor value" as the minimum cash generation by the project that converted in US dollars, allow the payment of the scheduled debt service. When establishing a floor value it is important that there is sufficient margin for deviations in the operational performance from the initially projected performance levels. The calculation to determine the possibility of cash shortfall is based on actual inflation and current exchange rates. In the event of a currency devaluation that results in the inability of the project to repay its debtsthat is the cash generation becomes insufficient to reach the floor value, the liquidity facility is temporarily drawn upon. A loan is made to the project's senior lenders to be paid back when the project's cash flow allows. This is presumed will happen when prices rise as devaluation will lead to increases in prices and tariffs.

Counter-cyclical guarantee facilities: It is widely accepted that international financial and banking markets tend to overestimate risk in difficult times and underestimate it in good times. As a result, private lenders are prone to boom-bust patterns that are often more determined by changing global preferences for risk aversion and/or contagion between developing countries, and not so much determined by country fundamentals. This provides a strong case for public institutions to play an explicit counter-cyclical role to help compensate for the inherent tendency of private flows to be pro cyclical, for example in long-term trade credit for infrastructure investment.

Sovereign Guarantee Pool (SGP): An alternative to mitigate currency and regulatory risks is to push forward regional20 efforts to create guarantee agencies that enable currency and regulatory risk sharing among countries that have common interests and projects and could benefit from the multiplier effect of infrastructure development in the neighbouring economies. These agencies could enhance the credit worthiness of single country members and therefore of their government guarantees. The guarantee agencies could provide pooling (on behalf of all member states) guarantees that will back the counter guarantees provided by host 
governments to MDBs and ECAs in the mechanisms described above. If carefully structured, an effective risk management system can achieve a better credit standing status. The cumulative effect of these combined bodies should prove to be credit worthier than the several different governments working separately. Initially, however, the mechanism would benefit primarily common projects between two countries. More specifically, a pilot plan would select infrastructure projects close to borders.

\subsection{Conceptual Framework}

The concept critically analyses Influence of environmental factors on financing of irrigation projects. The independent variables are key commercial risks, Major forms of PPP and key legal issues interacting with Guarantees to enable financing of irrigation project.

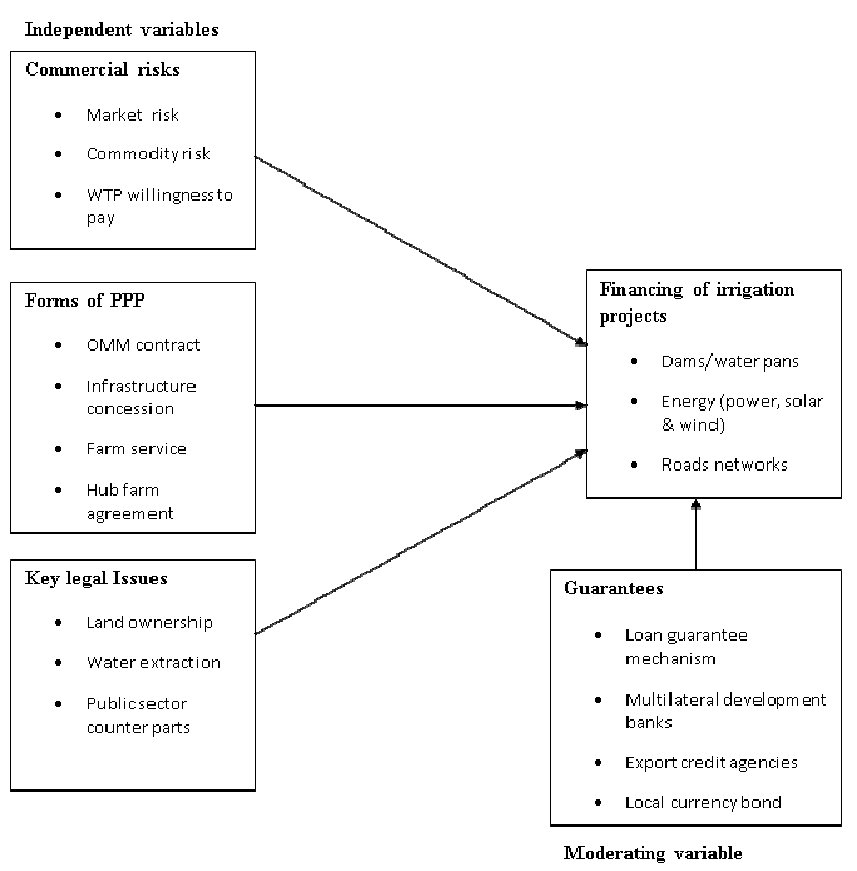

Fig. 1. conceptual framework.

\section{Conclusion}

The paper has examined Influence of environmental factors on financing of irrigation projects. It is acknowledged that Key Commercial risks; main contractual forms of PPPs, and key legal issues moderated by guarantees is key to financing and irrigation project. The key proposition made in this article has implications in financing and irrigation project. The implication is that a policy should be made by National Irrigation Board that small holder farmers aggregate their land and form cooperative societies. The formed societies will give them a voice for funding on commercial basis. In conclusion, it should be noted that not all concepts of Project Finance are feasible in financing and irrigation project, only Key issues in relation to Irrigation is applicable. From these tentative conclusions, it should be possible to develop and carry out empirical study.

\section{References}

[1] Benjamin C Esty and Aldo Sesia Jr. (2007), "An Overview of Project Finance and Infrastructure Finance", Harvard Business School.

[2] Dixit A. K \& Pindyck R.S. (1994).Investment under uncertainty. Princeton (NJ): Princeton University Press,

[3] Drew, S. A. (1995). Strategic benchmarking: innovation practices in financial institutions. International Journal of Bank Marketing, 13(1), 4-16.

[4] Engel, E., Fischer, R., and Galetovic, A. (2010).The Economics of infrastructure finance: Public Private Partnerships Versus public provision" EIB Papers, 15 (1), 41- 69. [Online] Available:www.eib.org/attachments/.../eibpapers/eibpapers 20 10_v15_n01_en (January,2011)

[5] Engel, E., Fischer, R., and Galetovic, A. (2001).Least-Present-Value-of Revenue Auctions and Highway Franchising. Journal of Political Economy, 109 (5), 993-1020.

[6] Buljevich, E. C., \& Park, Y. S. (1999). Project Financing and the International Financial Markets. Norwell, MA: Kluwer Academic Publishers.

[7] Engel, E., Fischer, R., and Galetovic, A. (1997b). Highway Franchising: Pitfalls and Opportunities. American Economic Review. Papers and Proceedings, 87 (2), 68 - 72

[8] Erridge, A., \& Greer, J., (2002). Partnerships and public procurement: building social capital through supply relations. Public Administration, $80 \quad$ (3), 503-522. http://dx.doi.org/10.1111/1467-9299.00315

[9] Esty, B. C. (2004). Why study large projects? An introduction to research on project finance. European Financial Management, 10(2), 213-224.

[10] Finnerty J D (1996), Project Financing: Asset-Based Financial Engineering, John Wiley \& Sons, p. 2, New York.

[11] Gelpern, Anna, and MituGulati. 2013. "The Wonder Clause."Journal of Comparative Economics no. 41 (2).

[12] Grimsey, D., \& Lewis, M.K., (2002). Evaluating the risks of public-private partnerships for infrastructure projects. International Journal of Project Management, 20 (2), 107-118. [Online] Available: www.elsevier.com/locate/ijproman 0263-7863/01/ PII: S0263-7863 (00)00040-5

[13] Guasch, J.L. (2004). Granting and Renegotiating Infrastructure Concessions: Doing it Right. The World Bank, Washington, DC.ISBN 0-8213-5792-1 e-ISBN 0-8213-5793-X.

[14] Griffith-Jones, S., 1998, The European Investment Fund; Its Relevanace for Infrastructure

[15] Private Investment in Brazil. Report prepared for IPEA and presented at BNDES, Rio, and October1998.

[16] Griffth-Jones, S., 1993, Loan Guarantees for large infrastructure projects: the issues and possible lessons for a European facility. Office for Official Publications of the European Communities: Luxembourg. 
[17] Levy, S.M. (1996).Build, Operate, Transfer: Paving the Road for Tomorrow's infrastructure. John Wiley \& Sons, New York, USA.

[18] Lewis M.K (1994). Banking on real estate: in Fair D.E., Raymond R. eds., The Competitiveness of financial institutions and centers in Europe. Dordrecht: Kluwer,

[19] Li, B., Akintoye, A., Edwards, P.J., \& Hardcastle, C. (2005b). Critical success factors for PPP/PFI projects in the UK construction industry. Construction Management and Economics, 23 (5), 459-471.

[20] Li, H., Cheng, E.W.L., \& Love, P.E.D. (2000).Partnering research in construction. Engineering, Construction and Architectural Management, 7 (1), 76-92.

[21] Martini C A, \& Lee D Q. (1996). Difficulties in infrastructure financing. Journal of Applied Finance and Investment, 1 (1) 24 -7 .

[22] Mistry, P., and N. Olesen, 2003, Mitigating Risks for Foreign Investments in Least Developed Countries, Ministry for Foreign Affairs, Sweden: Stockholm.

[23] Morris, M.H., Kuratko, D.F., \& Schindehutte, M. (2001).Towards Integrating: Understanding Entrepreneurship through frameworks. The International Journal of Entrepreneurship and Innovation, 2(1), 35-49.

[24] Nevitt P K and F J Fabozzi (2000), Project Financing, 7th Edition, Euromoney Books London, UK.
[25] Rajan, R. G., \&Zingales, L. (2003).The great reversals: the politics of financial development in the twentieth century. Journal of Financial Economics, 69(1), 5-50.

[26] Report No 13676: A Review of World Bank Experience in Irrigation. Operations and Evaluation Department, World Bank, Washington DC (1994).

[27] Rigby P and PenroseJ (2003), "Project Finance Summary Debt Rating Criteria", Standard \& Poor's Corporation, 2003-2004 Project \& Infrastructure Finance Review: Criteria and Commentary, October.

[28] Tang, L. Y., Qiping S. A., \& Eddie.(2009). A review of studies on Public-Private Partnership projects in the construction industry. International Journal of Project Management.

[29] World Bank 2001, Private Participation in Infrastructure Database [http://rru.worldbank.org/ppi/]

[30] World Resources Institute, 2002, Export Credit Agencies and the World Bank: A Need for Common Standards

[31] World Resources Institute, 2002, Export Credit Agencies and the World Bank: A Need for Common Standards

[32] Yescombe, E.R. (2002). Principles of Project Finance. Academic Press, New York, USA.

[33] Yescombe, E.R. (2007). Public-Private Partnerships: Principles of Policy and Finance. Butterworth-Heinemann, London, UK. 